\title{
Designing a Quality Model for justifying the Authenticity of Qualitative Research: Validation and Verification of References
}

\author{
Basit Habib ${ }^{1}$ \\ Bahauddin Zakariya University, Multan \\ Shahzad Mahmood 2 \\ Bahauddin Zakariya University, Multan \\ Mehreen Hashmi ${ }^{3}$ \\ Bahauddin Zakariya University, Multan \\ Sohail Khan Khakwani ${ }^{4}$ \\ Bahauddin Zakariya University, Multan
}

\begin{abstract}
The Research in social science has a vital impact on the historical background of different event. These events are to be studied under the umbrella of qualitative research methodology. This methodology is based on the critical overview of any event or set of events related to a certain problem statement. To evaluate the authenticity of such research which is conducted on the bases of oral history, it is neces sary to define a certain tool which is in hierarchy order and if qualitative research is to be conducted should be gone through using the certain tool. In this paper such a quality model is generated from various aspect of computational quality model which can be helpful for the social scientist to see the authenticity of the references and methodology used during the research of oral history.
\end{abstract}

\section{Keywords}

Quality Model, Factors, Criterion, References, Publishers, Citation, Forgetting modules

\section{Introduction}

This research discusses all the various aspects by which we can judge the reliability of Oral historyand qualitative approach in Social Sciences. The authenticity of such approach of study is described on some various main impacts such as the References coded, the data which is under seen and the interpretation of data. This work desires to see that if a researcher goes through some various steps or process than the work or statement which he is coding is authentic or not and should it be a part of his study?. For such identification a step-wise process is explained known to be such a Model which can identify the quality of the Reference, data under seen and interpretation. The tool which is used to calculate is a Quality Model, in which by following its various step we can justify the coded fact in any of the mentioned forms, (B. Habib, A. Ashfaq,, 2013)(Habib, 2013)(Neuman.L, 1998).

\section{Oral history}

Oral history is a collection of verbal account of historical information gathered. The oral history may be recorded on devices, filmed, written or memorized. The references of oral history like every commodity may have different scales of expiries or validities. Here the different intensities of validation of references are marked as the facilitator for the researchers. While Frank Wittingham Skemp was trying to learn Multani language nor mere intention to record the oral history. In the introductory note he argued that he was writing the stories as according to him it was the easiest way to learn the different dialects of Multani and Baluchi languages in the absence of proper available literature of these native tongues. So he didn't give a proper attention to the characters and chronologically important events of the stories. Those were just the folk-lore or fairy-tails which might be liked by the readers who have interest in the Multani language. But unintentionally he was writing the historical events of the Multan, Bahawalpur and Derajat (Dera Ghazi Khan, Dera Ismail Khan and Dera Fateh Khan) of some decades earlier rather he was writing the history of people of these area which had impacts ofcircumvolution of aeon and the events adjoins links of the chains of history of manydifferent cultures and nations of hand-full number of countries as India, Pakistan, Afghanistan, Iran, Turkey, former Russian States, etc. Therefore the references of oral and written history leads the researchers to more than five centuries in past. Professor Dr Ashiq Muhammad Khan Durrani referred Shahzada Ali Muhammad Khan Khudakka Sadozai's about Afghanistan and Multan history in his book and in his thesis, 'The Last Phase Of Mus lim Rule In Multan (1752 - 1818)', upto more than two and a half centuries in past whereas, Muhammad Sohail khan used the period of references more than five centuries in history with the chronological order. In the Multan account in the chronological list of rulers of Multan the dates are used many centuries 'Before the Emergence of Christ'. Yet the most references are used from the books as written accounts rather the mere oral history,(Sohail, 2014 )(Skemp, 1917).

This Quality Model for justifying the Authenticity of Qualitative Research: Validation and Verification of References will be of great help for researchers to verify the validation of references and will pave a path for the ongoing and future generations of qualitative as well as quantitative researchers too.

\subsection{What is a Quality Model?}

2278 | P a g e

Fe bruary, 2017

w w w. cirworld. com 
A quality model is a set of Factors and their Criterion. The main idea of a quality model is to show such attributes which help in solving a problem statement and justifying facts on reality basis in a systematic manner. A Quality model is based on a set of factors and these factors are based on a set of different criterions ,(B. Habib, A. Ashfaq,, 2013)(Habib, 2013).

\subsection{What is a Factor?}

In a quality model the factor or set of factors (as a quality model is based on a set of factors), when implemented on any problem statement or analysis of subject is the skeleton structure from head to toe which shows the positioning of steps to be followed for the measurement of authenticity. If the steps are properly merged into the bone then the skeleton becomes more and more strong, (B. Habib, A. Ashfaq,, 2013)(Habib, 2013).

\subsection{What is criterion?}

Criterion is the sub sets of a factor. They are the joints of the bones (factors) which show how the step can be projectedon a subject that shows the full im plementation of a problem statement and it's fully functionality regarding the authenticity, (Habib, 2013).

\subsection{Explanation of Factors}

\subsubsection{Integrity}

"The ability to detect, correct and response all errors or the extent under which the illegal access to data can be controlled" .The integrity ensures that the data cannotbe altered illegallyand access control that can be designed to prevent against this happening. Integrity deal with control of entering inaccurate data by detecting it if it happened, (B. Habib, A. Ashfaq,, 2013).

\subsubsection{Usability}

The effort to learn and handle a subject or the extent to which proposed function is meaningful and minimum chances of human error and proper functionality can be achieved .Usability may be defined as the extent to which a product can be used by specified user to achieve specified goal effectively, (B. Habib, A. Ashfaq,, 2013).

\subsubsection{Correctness}

The extent to which the required task can be done properlyor the extent to which a subject fulfill its specification regarding the desired need, or its importance with respect to our work,(B. Habib, A. Ashfaq,, 2013).

\subsubsection{Reliability}

The capacity that persistentlyperform their function and not fail to work during the processing of gaining the proper concept of a subject showing how much authentic it is so that it can be coded by seeing its expected role within a period of time to predefined condition. Reliability may be calculated between the failuretime, repairtime, recovertime, possibility of failure and availability of this subject, (B. Habib, A. Ashfaq,, 2013).

\subsubsection{Maintainability}

The cost of localizing and correct error or the Quality of design which determine the possibility that fails the aspect of the subject and can be restored to its normal operable state within timeframe using prescribed procedure, (B. Habib, A. Ashfaq,, 2013).

\subsubsection{Reusability}

The capacities of being used again and repeatedly of transferring the subject from one purpose to another purpose or its relationship in any scenario are when we can recall what is needed. One benefit of this factor is that once the subject is understood andis ready to be coded it can be used accurately with confidence .No need of testing again, (B. Habib, A. Ashfaq,, 2013).

\subsubsection{Interoperability}

The cost of connecting the two concepts with one another is known as interoperability. Ability of a concept to work with other concepts use the part of informationin the related work. This is a development technique that encourage the work developed in a manner that interacts with other product, (B. Habib, A. Ashfaq,, 2013).

\subsubsection{Flexibility}

The ability of the data being modified into such information which is usable for ensuring the subject is called flexibility. It is linked with adaptability i.e. being able to change or reconfigure the user problem statement to suit user preference, (B. Habib, A. Ashfaq,, 2013).

\subsubsection{Modifiability}

2279 | P a g e

F e b r u a ry, 2017 
Capacity of being modified or varied with respect to condition is called modification or modifiability. This is a strategy of any program that if some changes were apply on this then this program have capabilities to adapt this changes or modified successfully. Generallythis strategy is used to fulfill the weaknesses, correct the defects and to improve the performance, (B. Habib, A. Ashfaq,, 2013).

\subsubsection{Understandability}

Capacity of understanding or being comprehensible and capable of understanding the ability for act and responsive behavior upon the given strategy. This is how we can show a relationship between the information in the sphere being gathered and using it in the subject we are working in, (B. Habib, A. Ashfaq,, 2013).

\section{Seven Memory Problems}

The seven memory signs of forgetting are explained by Denial. L, in 1999. These signs tell us what are the problems due to which any person forgets any saying, quoted reference or even any incident. These signs are explain ed as under

\subsection{Transience}

This is tendency to forget facts or events over time most likely to forget information soon after you learn it. However with the passage of time memories use it or lose it quality of the data. Memories that are called up and used frequently are least likely to be forgotten whereas the memories which are recalled after some time have chances to be forgotten or remembered not with proper approach.Seem like sign of memoryweakness Brain scientist regard it as beneficial it clears the brain of unused memories making way for newer, more useful ones factors relate to transience, (Habib, 2013)(Schacter).

\subsubsection{Factors that relate to transience}

\begin{tabular}{|l|l|}
\hline Factors & \multicolumn{1}{|c|}{ Criterion } \\
\hline Correctness & Traceability, Completeness, Consistency \\
\hline Reliability & Consistency, Accuracy, Error Tolerance \\
\hline Integrity & Access Control, Access Audit \\
\hline Usability & Operability, Training, Communicativeness \\
\hline Maintainability & Simplicity, Conciseness, Modularity, Self descriptiveness \\
\hline Understandability & Legibility , Consistency, Self-descriptiveness , Structuredness, Condsness \\
\hline Modifiability & Structuredness, Augumentability \\
\hline
\end{tabular}

\section{Table.1 Factors of transience}

\subsection{Absentmindedness}

This type of forgetting occurs when an entity doesn't pay close enough attention to the event. The entity forgets where,when and in which state the data was being transferred in mind or was being used. A person was thinking of something else (or,perhaps. nothing in particular) so the brain did not encode information properly. It also involve forgetting to do something at a prescribed time i.e. taking about doing something or even while doing something not following the proper steps, (Habib, 2013)(Schacter).

\subsubsection{Factors that relate to Absentmindedness}

\begin{tabular}{|l|l|}
\hline Factors & Criterion \\
\hline Correctness & Traceability, Completeness, Consistency \\
\hline Reliability & Consistency, Accuracy, Error Tolerance \\
\hline Integrity & Access Control, Access Audit \\
\hline Maintainability & Simplicity, Instrumentation, Modularity \\
\hline Reusability & Simplicity, Sy stem Independence, Machine Independence \\
\hline Interoperability & Modularity, Communication Commonality, Data Commonality \\
\hline Modifiability & Structuredness, Augumentability \\
\hline
\end{tabular}

\section{Table.2Factors of Absentmindedness}




\subsection{Blocking}

If someone ask any query and the answer is right on the tip of the tongue, but cannot be explained in a proper manner verbally. This is perhaps the time is not right, or there is any other thing going in mind and also sometimes there are not words to explain it. Forgetting occurs when an item in memory cannot be accessed or retrieved. But Blocking is caused by Interference. This can de also due to the reas on of not being able to recall one memorybecause another similar memory is in the way, (Habib, 2013)(Schacter).

\subsubsection{Factors that relate to Blocking}

\begin{tabular}{|l|l|}
\hline Factors & \multicolumn{1}{|c|}{ Criterions } \\
\hline Correctness & Traceability, Completeness, Consistency \\
\hline Integrity & Access Control, Access Audit \\
\hline Usability & Operability, Training, Communicativeness \\
\hline Maintainability & Simplicity, Conciseness, Modularity, Self descriptiveness \\
\hline Flexibility & Simplicity, Expandability, Generality, Modularity \\
\hline Reusability & Simplicity, independence , \\
\hline Understandability & Legibility, Consistency, Self-descriptiveness , Structuredness, Condsness \\
\hline Modifiability & Structuredness, Augumentability \\
\hline
\end{tabular}

\section{Table.3Factors of Blocking}

\subsection{Misattribution}

Mis attribution occurs when you remember something accurately in part but misattribute some details like time, place or person involved. A memory fault that occurs when memories are retrieved or recovered, but are associated with wrong time, place or person .Connecting memories of event to wrong time, place or person is the concept of misfit ting those attributes which posses different nomenclatures. This state is called Misattribution, (Habib, 2013)(Schacter).

\subsubsection{Factors that relate to misattribution}

\begin{tabular}{|l|l|}
\hline Factors & Criterions \\
\hline Correctness & Traceability, Completeness, Consistency \\
\hline Reliability & Consistency, Accuracy, Error Tolerance \\
\hline Integrity & Access Control, Access Audit \\
\hline Maintainability & Simplicity, Conciseness, Modularity, Self descriptiveness \\
\hline Modifiability & Structuredness, Augumentability \\
\hline
\end{tabular}

\subsection{Suggestibility}

It is an acceptance of a false suggestion made by any other source. Memories of past are often influenced in different manners in which they are recalled. The process of memory distortion as the result of deliberate or inadvertent suggestion is where an entity has to give an argument. False butplausible information is given as a result memoryis altered. One fills the gaps in memory with false information when recalling a scenario or moment and relating it to other events for his argument, (Habib, 2013)(Schacter).

\subsubsection{Factors that relate to Suggestibility}

\begin{tabular}{|l|l|}
\hline Factors & Criterions \\
\hline Correctness & Traceability, Completeness, Consistency \\
\hline Reliability & Consistency, Accuracy, Error Tolerance \\
\hline Integrity & Access Control, Access Audit \\
\hline Usability & Operability, Training, Communicativeness \\
\hline
\end{tabular}

2281 | P a g e 


\begin{tabular}{|l|l|}
\hline Maintainability & Simplicity, Conciseness, Modularity, Self descriptiveness \\
\hline Flexibility & Simplicity, Expandability, Generality, Modularity ,Self descriptiveness \\
\hline Reusability & Simplicity, subject independence, Machine Independence \\
\hline Interoperability & Modularity, Communication commonality, Data Commonality \\
\hline Understandability & Legibility, Consistency, Self-descriptiveness , Structuredness, Condsness \\
\hline Modifiability & Structeredness, Augumentability \\
\hline
\end{tabular}

\section{Table.5Factors of Suggestibility}

\subsection{Bias}

Even the sharpestmemory is not flawless as regarding the picture of the reality. In the memory the perception are filtered by personal biases, experiences, beliefs, prior knowledge and even your mood at the moment. These biases affect your perceptions and experiences when they are being encoded in your brain and when you retrieve a memory your mood and other biases at that movement can influence what information you actually recall, (Schacter)(Habib, 2013).

\subsubsection{Factors that relate to Bias}

\begin{tabular}{|l|l|}
\hline Factors & Criterions \\
\hline Correctness & Traceability, Completeness, Consistency \\
\hline Reliability & Consistency, Accuracy, Error Tolerance \\
\hline Integrity & Access control, Access Audit \\
\hline Maintainability & Simplicity, Conciseness, Modularity, Self descriptiveness \\
\hline Understandability & Legibility, Consistency, Self-descriptiveness, Structuredness, Condsness \\
\hline Modifiability & Structuredness, Augumentability \\
\hline
\end{tabular}

\section{Table.6Factors of Bias}

\subsection{Persistence}

The failure of the memorysystem involves the unwanted recall of the information that is disturbing. The remembrance can range from a blunder on the job to a truly traumatic experience and the persistent recall can lead to phobias, post-traumatic stress dis order and even Suicide factor relate to persistence, (Habib, 2013)(Schacter).

\subsubsection{Factors that relate to Persistence}

\begin{tabular}{|l|l|}
\hline Factors & Criterions \\
\hline Correctness & Traceability , Completeness, Consistency \\
\hline Reliability & Consistency, Accuracy , Error Tolerance \\
\hline Maintainability & Simplicity, Conciseness, Modularity, Self descriptiveness \\
\hline Interoperability & Modularity , Communication commonality , Data Commonality \\
\hline Modifiability & Structuredness , Augumentability \\
\hline
\end{tabular}

Table.7Factors of Persistence 


\section{Explanation of Criterion regarding the quality model}

\begin{tabular}{|c|c|c|}
\hline Sr.No & Criterion & Definition \\
\hline 1. & Consistency & $\begin{array}{l}\text { Consistency as the quality criterion reflects consistent behavior of the person. Here it means that after every time } \\
\text { and manner the correctness/ reliability/ understandability remains at the same level. These quality factors directly } \\
\text { affect the behavior of the person in the changed/ modified circumstances and we still expect same level of } \\
\text { performance. Thus the consistency is desired. }\end{array}$ \\
\hline 2. & Modularity & $\begin{array}{l}\text { Modularity is the degree to which a subject component may be separated and recombined. it becomes far easier } \\
\text { to manage the final research if it is suitably modeled. }\end{array}$ \\
\hline 3. & Self Descriptiveness & $\begin{array}{l}\text { Self Descriptiveness provides simplicity by reducing person's memory load and improves his efficiency by letting } \\
\text { them retain their capacity for their tasks instead of bothering with the subject. Presence of this criterion } \\
\text { influences flexibility, maintainability, and testability as things go intuitively understood. }\end{array}$ \\
\hline 4. & Simplicity & $\begin{array}{l}\text { The property, condition, or quality of being simple. If simplicity has been induced into the subject it will be easier } \\
\text { to get maintained and tested. Moreover reusing the subject in different contexts will also be easier. }\end{array}$ \\
\hline 5. & Accuracy & $\begin{array}{l}\text { Accuracy is the condition or quality of the person's memory of being correct and freedom from error or defect. It } \\
\text { determines the degree of reliability and affects the functionality of the subject.. }\end{array}$ \\
\hline 6. & Communicativeness & $\begin{array}{l}\text { Communicativeness is the ability of the person to communicate its features to the user intuitively. It thus improves } \\
\text { its usability and enhances robustness, integrity, accessibility, and communicativeness of the involved humans. }\end{array}$ \\
\hline 7. & Conciseness & $\begin{array}{l}\text { Conciseness means shortness in size and } \\
\text { comprehensiveness in scope of the Subject. A compact and concise subject will not only be easy to comprehend, } \\
\text { but will also be easier to maintain because unnecessary details will have been removed. }\end{array}$ \\
\hline 8. & Structurednes s & $\begin{array}{l}\text { The state or condition of subject of being well-thought and ingenious is known as structurednes. A well structured } \\
\text { subject can be modified easily. Its understandability will no doubt be improved. }\end{array}$ \\
\hline 9. & Access Audit & $\begin{array}{l}\text { Access audit is to establish how well a subject performs in relation to exercise its control on access in the form of } \\
\text { information. }\end{array}$ \\
\hline 10. & Access Control & $\begin{array}{l}\text { Access control refers to exerting control over the subject and defines other different related issue with the subject } \\
\text { under seen. It basically shows the interaction of combined subjects related under a single problem statement. }\end{array}$ \\
\hline 11. & Accessibility & $\begin{array}{l}\text { Accessibility is the degree to which a subject is available to as many users as required. It thus improves its } \\
\text { usability and enhances robustness, integrity, accessibility, and communicativeness of the involved humans. }\end{array}$ \\
\hline 12. & Augment ability & $\begin{array}{l}\text { Augment ability is the capability of the subject to get additional features accommodated to coop with the fresh } \\
\text { requirements. So the subject can be modified to get adjusted to changed environment. }\end{array}$ \\
\hline 13. & Commonality & $\begin{array}{l}\text { Commonality is the possession of common features or attributes. This reduces the efforts required to couple one } \\
\text { subject to another. }\end{array}$ \\
\hline 14. & Completeness & $\begin{array}{l}\text { Completeness means that the requirements are properly fulfilled and correctness is the degree at which basic } \\
\text { principles have been followed. This forms the relation. }\end{array}$ \\
\hline 15. & Error tolerant & $\begin{array}{l}\text { Error tolerant subject is one that does not unduly penalize user errors. This property improves the ability of the } \\
\text { subject not to change its meaning while interoperating, and to interoperate as per originality. }\end{array}$ \\
\hline 16. & Expandability & $\begin{array}{l}\text { Expandability is the ability of a person to accommodate additions to its capacity or capabilities. It makes the } \\
\text { subject flexible by providing ease in making changes required by changes in the under seen environment. }\end{array}$ \\
\hline 17. & Traceability & $\begin{array}{l}\text { Traceability refers to the completeness of the information about every step in a process of subject development. It } \\
\text { improves correctness. }\end{array}$ \\
\hline 18. & Training & $\begin{array}{l}\text { Training is the action of teaching users proper use of the subject. Through this training person remain involve in } \\
\text { the working environment. }\end{array}$ \\
\hline 19. & Generality & $\begin{array}{l}\text { Such kind of statement which is based any truth but with the passage of time abstraction and expandation of that } \\
\text { certain statement changes is known as generality regarding its influence in any event or situation, }\end{array}$ \\
\hline 20. & Condenses & To reduces or shorten any event or statement is known as condenses. \\
\hline
\end{tabular}

\section{Table.8 Explanation of Criterion regarding the quality model}

2283 | P a g e 


\section{Appling test by showing relationship among references with factors of quality models}

In this test a research thesis named Gender in Oral History: A critical analysis of F.W Skemp's Multani stories, M.S. Khan written in 2015 and the original book Multani stories collected and translated by F.W. Skemp in 1917 are taken under seen. Five reference of each are taken randomlyand are scaled on the Quality Factors with reference to age of the reference, its publisher and citation of the reference,(Sohail, 2014 )(Skemp, 1917).

\begin{tabular}{|c|c|c|c|c|c|c|c|c|}
\hline Factor & Ref & rence & & & & & & \\
\hline \multirow[t]{12}{*}{ Correctness } & \multirow{2}{*}{$\begin{array}{l}\text { Sr. } \\
\text { No }\end{array}$} & \multirow{2}{*}{$\begin{array}{l}\text { Nature of } \\
\text { Subject }\end{array}$} & \multirow{2}{*}{$\begin{array}{l}\text { Age of } \\
\text { Reference }\end{array}$} & \multicolumn{3}{|c|}{ Publisher } & \multicolumn{2}{|c|}{ Citation } \\
\hline & & & & International & National & Verbal/Oral & International & $\begin{array}{l}\text { Nationa } \\
1\end{array}$ \\
\hline & \multirow[t]{5}{*}{1} & \multirow{5}{*}{$\begin{array}{l}\text { Qualitative/ Gender } \\
\text { in Oral History : A } \\
\text { Critical Analysis of } \\
\text { F.W. Skemp's, } \\
\text { Multani Stories }\end{array}$} & 1980 & & $\frac{2}{a}$ & & & $\checkmark$ \\
\hline & & & 2007 & & $\checkmark$ & & & $\checkmark$ \\
\hline & & & 1997 & & $\checkmark$ & & & $\checkmark$ \\
\hline & & & 1909 & $\checkmark$ & & & $\sqrt{2}$ & $\sqrt{2}$ \\
\hline & & & 1929 & $\checkmark$ & & & $\checkmark$ & $\checkmark$ \\
\hline & \multirow[t]{5}{*}{2} & \multirow{5}{*}{$\begin{array}{l}\text { Multani Stories } \\
\text { collected and } \\
\text { translated by F.W. } \\
\text { Skemp, } 1917\end{array}$} & 1914 & & $\checkmark \quad$ (Sub-Continent) & & $\checkmark$ & \\
\hline & & & 1787 & & & $\begin{array}{ll}\checkmark & \text { (Sub- } \\
\text { Contiment) }\end{array}$ & Nil & Nil \\
\hline & & & 1893 & & & $\begin{array}{ll} & \text { (Sub- } \\
& \text { Continent) }\end{array}$ & Nil & Nil \\
\hline & & & 1805 & & & $\begin{array}{|ll|}\checkmark & \text { (Sub- } \\
& \text { Continent) } \\
\end{array}$ & Nil & $\mathrm{Nil}$ \\
\hline & & & $1901-02$ & & $\checkmark$ (Sub-Continent) & & & $\sqrt{2}$ \\
\hline
\end{tabular}

Table.9Relationship of correctness with references

This table shows the references which were used mostly in the above mentioned subjects. Here in the above table 9 , the reference 1 showing the detail which is use in national publication and its citation also available on national level while on the other hand in the other reference which is used in 1909 and 1929 is use in international publication and while their citation also used at international level and national level. In the second reference which is related to the Multani stories collected and translated, in this the reference of 1914 is published at national level in the subcontinent and while the reference of 1787 , 1893,1805 is in the verbal/oral level and its citation also not available at international or national level. While the reference of 1901-02 is use at the national level publication and also in the verbal/oral level and its citation avail at the national level is available. Most of them are near about 100 years old. Regarding the quality model factor, correctness is used for to make a ground to judge the quality or certainty of a source, which justifies the age of the reference and its certainty, (Skemp, 1917)(Sohail, 2014 ).

\begin{tabular}{|c|c|c|c|c|c|c|c|c|}
\hline Factor & Ref & ence & & & & & & \\
\hline \multirow[t]{12}{*}{ Reliability } & \multirow{2}{*}{$\begin{array}{l}\text { So: } \\
\text { No }\end{array}$} & \multirow{2}{*}{$\begin{array}{l}\text { Nature of } \\
\text { Subject }\end{array}$} & \multirow{2}{*}{$\begin{array}{l}\text { Age of } \\
\text { Reference }\end{array}$} & \multicolumn{3}{|c|}{ Publisher } & \multicolumn{2}{|c|}{ Citation } \\
\hline & & & & International & National & Verbal/Oral & International & National \\
\hline & \multirow[t]{5}{*}{1} & \multirow{5}{*}{$\begin{array}{l}\text { Qualitative Gender } \\
\text { in Oral History: A } \\
\text { Critical Analysis of } \\
\text { F.W. Skemp : } \\
\text { Mulami Stories }\end{array}$} & $1980(\mathrm{No})$ & & $\checkmark$ (Yea) & & & $\checkmark(Y e s)$ \\
\hline & & & 2007 (Yes) & & $\checkmark($ Yes $)$ & & & $\checkmark(Y e a)$ \\
\hline & & & $\begin{array}{l}1997 \text { (To } \\
\text { some } \\
\text { extent) }\end{array}$ & & $\checkmark$ (Yes) & & & $\checkmark$ (Yes) \\
\hline & & & 1909 (No) & $\checkmark$ (Yes) & & & (Yes) & $\checkmark$ (Yes) \\
\hline & & & 1929 (No) & $\checkmark(Y e s)$ & & & (Yes) & $\checkmark($ Yes $)$ \\
\hline & \multirow[t]{5}{*}{2} & \multirow{5}{*}{$\begin{array}{l}\text { Multami Stories } \\
\text { collected ond } \\
\text { tramslated by F.W. } \\
\text { Sikemp. } 1917\end{array}$} & 1914 (No) & & $\begin{array}{l}\text { (Sub-Continent) } \\
\text { To some extent }\end{array}$ & & (Yent) & \\
\hline & & & $1787(\mathrm{No})$ & & & (Sub- & $\begin{array}{l}\mathrm{Nal} \\
\text { (No) }\end{array}$ & $\begin{array}{l}\mathrm{Nal} \\
\text { (No) }\end{array}$ \\
\hline & & & $1893(\mathrm{No})$ & & & $\begin{array}{l}\text { (Sub- } \\
\text { Contiment) } \\
\text { No }\end{array}$ & $\begin{array}{l}\mathrm{Nl} \\
\text { (No) }\end{array}$ & $\begin{array}{l}\mathrm{Nal} \\
\text { (No) }\end{array}$ \\
\hline & & & 1805 (No) & & & $\begin{array}{l}\text { (Sub- } \\
\text { Contiment) } \\
\text { No }\end{array}$ & $\begin{array}{l}\mathrm{Nil} \\
\text { (No) }\end{array}$ & $\begin{array}{l}\mathrm{Nil} \\
\text { (No) }\end{array}$ \\
\hline & & & $\begin{array}{l}1901.02 \\
(\mathrm{No})\end{array}$ & & $\begin{array}{l}\text { (Sub.Continent) } \\
\text { To some extent }\end{array}$ & & & $(\mathrm{Y} \in \mathrm{B})$ \\
\hline
\end{tabular}

Table.10Relationship of correctness with reliability

The measures regarding reliability are defined in to different manners, either Yes or No. Reliability is based on the concept when we take all the references with respect to the current era. By the judgment of references regarding 'today' the authenticity of the reference is seen by looking at its age. On the other hand the sub entities of reference such as its source 
also plays a vital role in the verification of the reliability of a reference, (Sohail, 2014 )(Skemp, 1917). Here in the above table 10 , the reference of 1980 showing the detail which is use in national publication and its citation also available on national level while on the other hand in the other reference which is used in 2007 and 1997 is also use in national publication and while their citation also used national level . in two other reference 1908, 1929 are available in international publication and there citation also available in the international and nation level. In the second reference which is related to the Multani stori es collected and translated, in this the reference of 1914 and 1901-02 available in national level in subcontinent and the reference of 1987, 1893, 1805 are available in the verbal/ oral level publication and the citation also not available in international or national level.

\begin{tabular}{|c|c|c|c|c|c|c|c|c|}
\hline Factor & Ref & rence & & & & & & \\
\hline \multirow[t]{12}{*}{ Integrity } & \multirow{2}{*}{$\begin{array}{l}\text { Sr. } \\
\text { No }\end{array}$} & \multirow{2}{*}{$\begin{array}{l}\text { Nature of } \\
\text { Subject }\end{array}$} & \multirow{2}{*}{$\begin{array}{l}\text { Age of } \\
\text { Reference }\end{array}$} & \multicolumn{3}{|c|}{ Publisher } & \multicolumn{2}{|c|}{ Citation } \\
\hline & & & & International & National & Verbal/Oral & International & National \\
\hline & \multirow[t]{5}{*}{1} & \multirow{5}{*}{$\begin{array}{l}\text { Qualitative/ Gender } \\
\text { in Oral History : A } \\
\text { Critical Analysis of } \\
\text { F.W. Skemp. S, } \\
\text { Multani Stories }\end{array}$} & 1980(Certain) & & $\checkmark \quad$ (Yes) & & & $\checkmark$ (Yes) \\
\hline & & & 2007 (Certain) & & $\begin{array}{ll}\text { (Yes) } \\
\end{array}$ & & & $\checkmark$ (Yes) \\
\hline & & & 1997 (Certain) & & $\checkmark$ (Yes) & & & $\checkmark$ (Yes) \\
\hline & & & $\begin{array}{l}1909 \\
\text { (Un-certain) }\end{array}$ & $\checkmark \quad$ (Yes) & & & $\checkmark \quad$ (Yes) & $\checkmark$ (Yes) \\
\hline & & & $\begin{array}{l}1929 \\
\text { (Un-certain) }\end{array}$ & $\checkmark \quad$ (Yes) & & & $\checkmark \quad$ (Yes) & $\checkmark$ (Yes) \\
\hline & \multirow[t]{5}{*}{2} & \multirow{5}{*}{$\begin{array}{l}\text { Multani Stories } \\
\text { collected and } \\
\text { translated by F.W. } \\
\text { Skemp, } 1917\end{array}$} & $\begin{array}{l}1914 \\
\text { (Certain) }\end{array}$ & & $\begin{array}{l}\text { (Sub-Continent) } \\
\text { To some extent }\end{array}$ & & $\checkmark \quad$ (Yes) & \\
\hline & & & $\begin{array}{l}1787 \\
\text { (Un-certain) }\end{array}$ & & & $\begin{array}{l}\text { (Sub- } \\
\text { Continent) } \\
\text { No }\end{array}$ & $\begin{array}{l}\text { Nil } \\
\text { (No) }\end{array}$ & $\begin{array}{l}\text { Nil } \\
\text { (No) }\end{array}$ \\
\hline & & & 1893 (Certain) & & & $\begin{array}{l}\text { (Sub- } \\
\text { Continent) } \\
\text { No }\end{array}$ & $\begin{array}{l}\mathrm{Nil} \\
\text { (No) }\end{array}$ & $\begin{array}{l}\text { Nil } \\
\text { (No) }\end{array}$ \\
\hline & & & $\begin{array}{l}1805 \\
\text { (Un-certain) }\end{array}$ & & & $\begin{array}{ll}\checkmark & \text { (Sub- } \\
\text { Contiment) } \\
\text { No } \\
\end{array}$ & $\begin{array}{l}\mathrm{Nil} \\
\text { (No) }\end{array}$ & $\begin{array}{l}\text { Nil } \\
\text { (No) }\end{array}$ \\
\hline & & & $\begin{array}{l}1901-02 \\
\text { (Certain) }\end{array}$ & & $\begin{array}{l}\text { (Sub-Continent) } \\
\text { To some extent }\end{array}$ & & & (Yes) \\
\hline
\end{tabular}

Table.11Relationship of correctness with integrity

Integrity by definition means to see the how right a statement or a reference is. Integrity is based on the probable values by which it can be seen how certain or uncertain the trend of a statement or a reference exists. By the combination of integrity as a factor on different signs of forgetting in the above mentioned subjects, the integrity will be seen in the perceptive era's of the subject individually, (Skemp, 1917)(Sohail, 2014). Here in the above table 11, the reference of 1980, 2007, 1997 showing the detail which is use in national publication and its citation also available on national level while on the other hand in the other reference which is used in 1909 and 1929 are use in international publication and while their citation also available at the international level and national level. In the second reference which is related to the Multani stories collected and transla ted, in this the reference of 1914 and 1901-02 available in national level in subcontinent and the reference of 1987,1893, 1805 are available in the verbal/ oral level publication and the citation also not available in international or national level.

\begin{tabular}{|c|c|c|c|c|c|c|c|c|}
\hline \multirow{3}{*}{$\begin{array}{l}\text { Factor } \\
\text { Usability }\end{array}$} & \multicolumn{8}{|c|}{ Reference } \\
\hline & \multirow{2}{*}{$\begin{array}{l}\text { Sr. } \\
\text { No }\end{array}$} & \multirow{2}{*}{$\begin{array}{l}\text { Nature of } \\
\text { Subject }\end{array}$} & \multirow[t]{2}{*}{ Age of Reference } & \multicolumn{3}{|c|}{ Publisher } & \multicolumn{2}{|c|}{ Citation } \\
\hline & & & & International & National & Verbal/Oral & International & National \\
\hline & \multirow[t]{5}{*}{1} & \multirow{5}{*}{$\begin{array}{l}\text { Qualitative' } \\
\text { Gender in } \\
\text { Oral History } \\
\text { :A Critical } \\
\text { Analysis of } \\
\text { F.W. } \\
\text { Skemp's, } \\
\text { Multani. } \\
\text { Stories }\end{array}$} & 1980 (Agree) & & $\checkmark \quad($ Yes) & & & $\checkmark$ (Yes) \\
\hline & & & 2007 (Strongly Agree) & & $\checkmark \quad$ (Yes) & & & $\checkmark$ (Yes) \\
\hline & & & 1997 (Strongly Agree) & & (Yes) & & & $\checkmark$ (Yes) \\
\hline & & & $\begin{array}{l}1909 \\
\text { (Strongly disagree) }\end{array}$ & $\checkmark \quad$ (Yes) & & & $\checkmark \quad$ (Yes) & $\checkmark$ (Yes) \\
\hline & & & $\begin{array}{l}1929 \\
\text { (Disagree) }\end{array}$ & $\checkmark \quad$ (Yes) & & & $\checkmark \quad$ (Yes) & $\checkmark$ (Yes) \\
\hline & \multirow[t]{5}{*}{2} & \multirow{5}{*}{$\begin{array}{l}\text { Multani } \\
\text { Stories } \\
\text { collected } \\
\text { and } \\
\text { translated by } \\
\text { F.W. Skemp. } \\
1917\end{array}$} & $\begin{array}{l}1914 \\
\text { (Strongly Agree) }\end{array}$ & & $\begin{array}{l}\text { (Sub-Continent) } \\
\text { To some extent }\end{array}$ & & $\checkmark \quad$ (Yes) & \\
\hline & & & $\begin{array}{l}1787 \\
\text { (Strongly disagree) }\end{array}$ & & & $\begin{array}{l}\text { (Sub- } \\
\text { Continent) } \\
\text { No }\end{array}$ & $\begin{array}{l}\text { Nil } \\
(\mathrm{No})\end{array}$ & $\begin{array}{l}\text { Nil } \\
\text { (No) }\end{array}$ \\
\hline & & & $\begin{array}{l}1893 \\
\text { (Agree) }\end{array}$ & & & $\begin{array}{l}\text { (Sub- } \\
\text { Continent) } \\
\text { No }\end{array}$ & $\begin{array}{l}\text { Nil } \\
\text { (No) }\end{array}$ & $\begin{array}{l}\text { Nil } \\
\text { (No) }\end{array}$ \\
\hline & & & $\begin{array}{l}1805 \\
\text { (Strongly disagree) }\end{array}$ & & & $\begin{array}{l}\text { (Sub- } \\
\text { Continent) } \\
\text { No }\end{array}$ & $\begin{array}{l}\text { Nil } \\
\text { (No) }\end{array}$ & $\begin{array}{l}\text { Nil } \\
\text { (No) }\end{array}$ \\
\hline & & & $\begin{array}{l}1901-02 \\
\text { (Strongly agree) }\end{array}$ & & $\begin{array}{ll}\text { (Sub-Continent) } \\
\text { To some extent }\end{array}$ & & & (Yes) \\
\hline
\end{tabular}

\section{Table.12Relationship of correctness with usability}

Usability define how much, how to and when any reference can be quoted. Usability is a set 5 scaler attributes named as strongly

2285 | P a g e 
Agree, Agree, Neutral, disagree and Stronglydisagree. Usability as a factor of a quality model when correlate which the sign of forgetting describes that the reference quoted is certain in its subject in the existing timeline within its own domain. Either that reference is new or possesses a certain age it will be considered usable in its era, (Skemp, 1917). Here in the above table 12 , the reference of $1980,2007,1997$ showing the detail which is use in national publication and its citation also available on national level while on the other hand in the other reference which is used in 1909 and 1929 are use in international publication and while their citation also available at the international level and national level. In the second reference wh ich is related to the Multani stories collected and translated, in this the reference of 1914 and 1901-02 available in national level in subcontinent and the reference of $1987,1893,1805$ are available in the verbal/ oral level publication and the citation also not available in international or national level.

\begin{tabular}{|c|c|c|c|c|c|c|c|c|}
\hline \multirow{3}{*}{$\begin{array}{l}\text { Factor } \\
\begin{array}{l}\text { Maintain } \\
\text { ability }\end{array}\end{array}$} & \multicolumn{8}{|c|}{ Reference } \\
\hline & \multirow{2}{*}{$\begin{array}{l}\text { Sr. } \\
\text { No }\end{array}$} & \multirow{2}{*}{$\begin{array}{l}\text { Nature of } \\
\text { Subject }\end{array}$} & \multirow[t]{2}{*}{ Age of Reference } & \multicolumn{3}{|c|}{ Publisher } & \multicolumn{2}{|c|}{ Citation } \\
\hline & & & & International & National & Verbal/Oral & International & National \\
\hline & \multirow[t]{5}{*}{1} & \multirow{5}{*}{$\begin{array}{l}\text { Qualitative/ } \\
\text { Gender in } \\
\text { Oral History } \\
\text { :A Critical } \\
\text { Analysis of } \\
\text { F.W. } \\
\text { Skemp's, } \\
\text { Multani } \\
\text { Stories }\end{array}$} & 1980(Patch) & & $\checkmark$ (Yes) & & & $\checkmark$ (Yes) \\
\hline & & & 2007 (Patch) & & $\begin{array}{ll}\checkmark \text { (Yes) } \\
\end{array}$ & & & $\checkmark$ (Yes) \\
\hline & & & 1997 (Patch) & & $\checkmark \quad$ (Yes) & & & $\checkmark($ Yes $)$ \\
\hline & & & $\begin{array}{l}1909 \\
\text { (Replace) }\end{array}$ & $\checkmark \quad$ (Yes) & & & $\checkmark \quad$ (Yes) & $\checkmark$ (Yes) \\
\hline & & & $\begin{array}{l}1929 \\
\text { (Replace) }\end{array}$ & $\checkmark \quad$ (Yes) & & & $\checkmark \quad$ (Yes) & $\checkmark$ (Yes) \\
\hline & \multirow[t]{5}{*}{2} & \multirow{5}{*}{$\begin{array}{l}\text { Multani } \\
\text { Stories } \\
\text { collected } \\
\text { and } \\
\text { translated by } \\
\text { F.W. Skemp, } \\
1917\end{array}$} & $\begin{array}{l}1914 \\
\text { (Patch) }\end{array}$ & & $\begin{array}{cc} & \text { (Sub-Contiment) } \\
\text { To some extent }\end{array}$ & & $\checkmark$ (Yes) & \\
\hline & & & $\begin{array}{l}1787 \\
\text { (Replace) }\end{array}$ & & & $\begin{array}{l}\text { (Sub- } \\
\text { Continent) } \\
\text { No }\end{array}$ & $\begin{array}{l}\mathrm{Nil} \\
\text { (No) }\end{array}$ & $\begin{array}{c}\text { Nil } \\
(\mathrm{No})\end{array}$ \\
\hline & & & $\begin{array}{l}1893 \\
\text { (Replace) }\end{array}$ & & & $\begin{array}{l}\text { (Sub- } \\
\text { Continent) } \\
\text { No }\end{array}$ & $\begin{array}{l}\mathrm{Nil} \\
\text { (No) }\end{array}$ & $\begin{array}{l}\mathrm{Nil} \\
\text { (No) }\end{array}$ \\
\hline & & & $\begin{array}{l}1805 \\
\text { (Replace) }\end{array}$ & & & $\begin{array}{l}\text { (Sub- } \\
\text { Continent) } \\
\text { No }\end{array}$ & $\begin{array}{l}\mathrm{Nil} \\
(\mathrm{No})\end{array}$ & $\begin{array}{l}\text { Nil } \\
(\mathrm{No})\end{array}$ \\
\hline & & & $\begin{array}{l}1901-02 \\
\text { (Patch) }\end{array}$ & & \begin{tabular}{|l} 
(Sub-Continent) \\
To some extent
\end{tabular} & & & $\checkmark$ (Yes) \\
\hline
\end{tabular}

Table.13 Relationship of correctness with maintainability

Maintainability is one of the most important factors which describes how a reference is maintained directly proportional with its age. If a reference has a large time span and it does not fulfill the requirement of publishers and citation than its image is replaced. This replacement can work from time to time in new era. If on the other hand the reference does not possess an age factor, in this state it has a precedence regarding its publisher or citation but has a dull image then a patch is inserted for its maintainability, (Skemp, 1917)(Sohail, 2014 ). Here in the above table 13, the reference of 1980, 2007, 1997 showing the detail which is use in national publication and its citation also available on national level while on the other hand in the other reference which is used in 1909 and 1929 are use in international publication and while their citation also available at the international level and national level. In the second reference which is related to the Multani stories collected and translated, in this the reference of 1914 and 1901-02 available in national level in subcontinent and the reference of 1987,1893, 1805 are available in the verbal/ oral level publication and the citation also not available in international or national level.

\begin{tabular}{|c|c|c|c|c|c|c|c|c|}
\hline \multirow{3}{*}{$\begin{array}{l}\text { Factor } \\
\text { Flexibility }\end{array}$} & \multicolumn{8}{|c|}{ Reference } \\
\hline & \multirow{2}{*}{$\begin{array}{l}\text { Sr. } \\
\text { Ne }\end{array}$} & \multirow{2}{*}{$\begin{array}{l}\text { Nature of } \\
\text { Subject }\end{array}$} & \multirow[t]{2}{*}{ Age of Reference } & \multicolumn{3}{|c|}{ Publisher } & \multicolumn{2}{|c|}{ Citation } \\
\hline & & & & International & National & Verbal/Oral & International & National \\
\hline & \multirow[t]{5}{*}{1} & \multirow{5}{*}{$\begin{array}{l}\text { Qualitative } \\
\text { Gender in } \\
\text { Oral History } \\
\text { A Critical } \\
\text { Ansly yix of } \\
\text { F.W. } \\
\text { Skemp's. } \\
\text { Multeni } \\
\text { Storiea }\end{array}$} & 1980 (Decreane) & & $\checkmark$ (Yen) & & & $\checkmark(\mathrm{Yen})$ \\
\hline & & & 2007 (Decrease) & & $(Y \in S)$ & & & $\checkmark$ (Yes) \\
\hline & & & 1997 (Decrease) & & (Yes) & & & $\checkmark(Y e s)$ \\
\hline & & & $\begin{array}{l}1909 \\
\text { (Increane) }\end{array}$ & $\checkmark(\mathrm{Yes})$ & & & (Yes) & $\checkmark$ (YिE) \\
\hline & & & $\begin{array}{l}1929 \\
\text { (Increase) }\end{array}$ & $\checkmark \quad(Y e s)$ & & & (Yes) & $\checkmark(\mathrm{Yes})$ \\
\hline & \multirow[t]{5}{*}{2} & \multirow{5}{*}{$\begin{array}{l}\text { Multani } \\
\text { Storien } \\
\text { collected } \\
\text { and } \\
\text { translated by } \\
\text { F.W. Skemp. } \\
\text { 1917 }\end{array}$} & $\begin{array}{l}1914 \\
\text { (Increase) }\end{array}$ & & $\begin{array}{l}\text { (Sub.Contment) } \\
\text { To nome extent }\end{array}$ & & (Yes) & \\
\hline & & & $\begin{array}{l}1787 \\
\text { (therease) }\end{array}$ & & & $\begin{array}{l}\text { (Sub- } \\
\text { Continent } \\
\text { No }\end{array}$ & $\begin{array}{l}\text { Na } \\
\text { (No) }\end{array}$ & $\begin{array}{l}\text { Nal } \\
\text { (No) }\end{array}$ \\
\hline & & & $\begin{array}{l}\text { I893 } \\
\text { (Increase) }\end{array}$ & & & $\begin{array}{l}\text { (Sub- } \\
\text { Contiment } \\
\text { No }\end{array}$ & $\begin{array}{l}\text { Nal } \\
\text { (No) }\end{array}$ & $\begin{array}{l}\mathrm{Nal} \\
\text { (No) }\end{array}$ \\
\hline & & & $\begin{array}{l}1805 \\
\text { (lncreane) }\end{array}$ & & & $\begin{array}{l}\text { (Sub- } \\
\text { Continent) } \\
\text { No }\end{array}$ & Nal & Nal \\
\hline & & & $\begin{array}{l}1901-02 \\
\text { (Increane) }\end{array}$ & & $\begin{array}{l}\text { (Sub-Continent) } \\
\text { To some extant }\end{array}$ & & & (Yes) \\
\hline
\end{tabular}

\section{Table.14Relationship of correctness with flexibility}

Flexibility is a factor which is in itself a very comprehensive argument. The age of the reference has a vital relationship with flexibility. A common scenario describe more the age of the reference will have more flexibility. This problem occurs when the 
publisher is not defined and most of the contents are the part of verbal/oral. Flexibility is seen with the passage of the time, such as any reference quoted either today or hundred years before will be considered in the frame of today's timeline. This is how we determine the increase and decrease rate of how much a reference is flexible, (Skemp, 1917)(Sohail, 2014 ). Here in the above table 14, the reference of 1980, 2007, 1997 showing the detail which is use in national publication and its citati on also available on national level while on the other hand in the other reference which is used in 1909 and 1929 are use in international publication and while their citation also available at the international level and national level. In the second reference which is related to the Multani stories collected and translated, in this the reference of 1914 and $1901-02$ available in national level in subcontinent and the reference of 1987,1893, 1805 are available in the verbal/ oral level publication and the citation also not available in international or national level.

\begin{tabular}{|c|c|c|c|c|c|c|c|c|}
\hline \multirow{3}{*}{$\begin{array}{l}\text { Factor } \\
\text { Portable }\end{array}$} & \multicolumn{8}{|c|}{ Reference } \\
\hline & \multirow{2}{*}{$\begin{array}{l}\text { Sr. } \\
\text { No }\end{array}$} & \multirow{2}{*}{$\begin{array}{l}\text { Nature of } \\
\text { Subject }\end{array}$} & \multirow[t]{2}{*}{ Age of Reference } & \multicolumn{3}{|c|}{ Publisher } & \multicolumn{2}{|c|}{ Citation } \\
\hline & & & & International & National & Verbal/Oral & International & National \\
\hline & \multirow[t]{5}{*}{1} & \multirow{5}{*}{$\begin{array}{l}\text { Qualitative/ } \\
\text { Gender in } \\
\text { Oral History } \\
\text { :A Critical } \\
\text { Analysis of } \\
\text { F.W. } \\
\text { Skemp's, } \\
\text { Muplani } \\
\text { Stories }\end{array}$} & 1980 (Likely) & & $\checkmark \quad$ (Yes) & & & $\checkmark$ (Yes) \\
\hline & & & 2007 (Even Chance) & & $\begin{array}{ll} & \text { (Yes) }\end{array}$ & & & $\checkmark$ (Yes) \\
\hline & & & 1997 (Even Chance) & & $\checkmark \quad$ (Yes) & & & $\checkmark$ (Yes) \\
\hline & & & $\begin{array}{l}1909 \\
\text { (impossible) }\end{array}$ & $\checkmark$ (Yes) & & & $\checkmark \quad$ (Yes) & $\checkmark$ (Yes) \\
\hline & & & $\begin{array}{l}1929 \\
\text { (impossible) }\end{array}$ & $\checkmark$ (Yes) & & & $\checkmark \quad$ (Yes) & $\checkmark$ (Yes) \\
\hline & \multirow[t]{5}{*}{2} & \multirow{5}{*}{$\begin{array}{l}\text { Multani } \\
\text { Stories } \\
\text { collected } \\
\text { and } \\
\text { translated by } \\
\text { F.W. Skemp. } \\
1917\end{array}$} & $\begin{array}{l}1914 \\
\text { (impossible) }\end{array}$ & & \begin{tabular}{|ll} 
& (Sub-Continent) \\
& To some extent
\end{tabular} & & $\checkmark \quad$ (Yes) & \\
\hline & & & $\begin{array}{l}1787 \\
\text { (impossible) }\end{array}$ & & & $\begin{array}{l}\text { (Sub- } \\
\text { Continent) } \\
\text { No }\end{array}$ & $\begin{array}{l}\mathrm{Nil} \\
\text { (No) }\end{array}$ & $\begin{array}{l}\mathrm{Nil} \\
\text { (No) }\end{array}$ \\
\hline & & & $\begin{array}{l}1893 \\
\text { (impossible) }\end{array}$ & & & $\begin{array}{l}\text { (Sub- } \\
\text { Contiment) } \\
\text { No }\end{array}$ & $\begin{array}{l}\text { Nil } \\
\text { (No) }\end{array}$ & $\begin{array}{l}\mathrm{Nil} \\
\text { (No) }\end{array}$ \\
\hline & & & $\begin{array}{l}1805 \\
\text { (impossible) }\end{array}$ & & & $\begin{array}{l}\text { (Sub- } \\
\text { Continent) } \\
\text { No }\end{array}$ & $\begin{array}{l}\text { Nil } \\
\text { (No) }\end{array}$ & $\begin{array}{l}\mathrm{Nil} \\
\text { (No) }\end{array}$ \\
\hline & & & $\begin{array}{l}1901-02 \\
\text { (impossible) }\end{array}$ & & \begin{tabular}{|l} 
(Sub-Contiment) \\
To some extent
\end{tabular} & & & $\checkmark \quad$ (Yes) \\
\hline
\end{tabular}

Table.15Relationship of correctness with portable

Portable is a term derived from portability. This factor shows that how a reference is explained in various problem statements regarding various time spans. This factor relies on five different attributes which show the portability of a same reference in different problem statements can be very same, likely to be same, not same or in a certain manner. The reference varies between these attributes. The interpretation regarding portable is within a time line either it is quoted in any time space, (Skemp, 1917)(Sohail, 2014). Here in the above table 15, the reference of 1980, 2007,1997 showing the detail which is use in national publication and its citation also available on national level while on the other hand in the other reference which is used in 1909 and 1929 are use in international publication and while their citation also available at the international level and national level. In the second reference which is related to the Multani stories collected and translated, in this the referen ce of 1914 and 1901-02 available in national level in subcontinent and the reference of 1987,1893, 1805 are available in the verba // oral level publication and the citation also not available in international or national level.

\begin{tabular}{|c|c|c|c|c|c|c|c|c|}
\hline \multirow{3}{*}{$\begin{array}{l}\text { Factor } \\
\text { Reusability }\end{array}$} & \multicolumn{8}{|c|}{ Reference } \\
\hline & \multirow{2}{*}{$\begin{array}{l}\text { Sis. } \\
\text { No }\end{array}$} & \multirow{2}{*}{$\begin{array}{l}\text { Nature of } \\
\text { Subject }\end{array}$} & \multirow[t]{2}{*}{ Age of Reference } & \multicolumn{3}{|c|}{ Publisher } & \multicolumn{2}{|c|}{ Citation } \\
\hline & & & & International & National & VerbsL/Oral & International & National \\
\hline & \multirow[t]{5}{*}{1} & \multirow{5}{*}{$\begin{array}{l}\text { Qualitative } \\
\text { Gender in } \\
\text { Oral History } \\
\text { A Critical } \\
\text { Anslysis of } \\
\text { F.W. } \\
\text { Skemo's } \\
\text { Multani } \\
\text { Stories }\end{array}$} & 1980 (Neutral) & & $\checkmark(\mathrm{Yes})$ & & & $\checkmark$ (Yes) \\
\hline & & & 2007 (Neutrad) & & $\checkmark$ (Yes) & & & $\checkmark$ (Yes) \\
\hline & & & 1997 (Neutral) & & $(\mathrm{Y})$ & & & $\checkmark(Y e i)$ \\
\hline & & & $\begin{array}{l}1909 \\
\text { (Strongly disagree) }\end{array}$ & $\checkmark(Y e s)$ & & & $(\mathrm{Yes})$ & $\checkmark$ (Yes) \\
\hline & & & $\begin{array}{l}1929 \\
\text { (Strongly disagree) }\end{array}$ & $\checkmark(Y e s)$ & & & $(Y e s)$ & $\checkmark$ (Yes) \\
\hline & \multirow[t]{5}{*}{2} & \multirow{5}{*}{$\begin{array}{l}\text { Multani } \\
\text { Stories } \\
\text { oollected } \\
\text { and } \\
\text { transated by } \\
\text { F.W. Skemp. } \\
1917\end{array}$} & $\begin{array}{l}1914 \\
\text { (Strongly disagree) }\end{array}$ & & $\begin{array}{l}\text { (Sub-Continent) } \\
\text { To some extent }\end{array}$ & & (Yes) & \\
\hline & & & $\begin{array}{l}1787 \\
\text { (Strongly disagree) }\end{array}$ & & & $\begin{array}{l}\text { (Sub- } \\
\text { Continent) } \\
\text { No }\end{array}$ & $\begin{array}{l}\mathrm{Nil} \\
\text { (No) }\end{array}$ & $\begin{array}{c}\mathrm{Ni} \\
\text { (No) }\end{array}$ \\
\hline & & & $\begin{array}{l}1593 \\
\text { (Strongly disagree) }\end{array}$ & & & $\begin{array}{l}\text { (Sub- } \\
\text { Contiment) } \\
\text { No }\end{array}$ & $\begin{array}{l}\text { Nil } \\
\text { (No) }\end{array}$ & $\begin{array}{l}\text { Nal } \\
\text { (No) }\end{array}$ \\
\hline & & & $\begin{array}{l}1805 \\
\text { (Strongly disagree) }\end{array}$ & & & $\begin{array}{l}\text { (Sub- } \\
\text { Continent) } \\
\text { No }\end{array}$ & $\begin{array}{l}\mathrm{Nal} \\
\text { (No) }\end{array}$ & $\begin{array}{l}\text { Nal } \\
\text { (No) }\end{array}$ \\
\hline & & & $\begin{array}{l}1901.02 \\
\text { (Strongly disagree) }\end{array}$ & & $\begin{array}{l}\text { (Sub-Contment) } \\
\text { To some extent }\end{array}$ & & & (Yea) \\
\hline
\end{tabular}

Table.16Relationship of correctness with reusability

2287 | P a g e 
Reusability is such a factor which determine how and where to reuse a reference on the basis of its age. It is simple phenomenon, more the age of the reference less it should be used. And if an aged reference is quoted then it should be scaled regarding it's usage in terms of applying Likert scale explained as stronglyagree, agree, neutral, disagree and strongly disagree. One thing is to be seemed that the factor of reusability is dependent on other factors of the model which includes usabilityand reliability, (Sohail, 2014 )(Skemp, 1917). Here in the above table 16, the reference of 1980, 2007 , 1997 showing the detail which is use in national publication and its citation also available on national level while on the other hand in the other reference which is used in 1909 and 1929 are use in international publication and while their citation also available at the international level and national level. In the second reference which is related to the Multani stories collected and translated, in this the reference of 1914 and 1901-02 available in national level in subcontinent and the reference of $1987,1893,1805$ are available in the verbal/ oral level publication and the citation also not available in international or $n$ ational level.

\begin{tabular}{|c|c|c|c|c|c|c|c|c|}
\hline \multirow{3}{*}{\begin{tabular}{|l|} 
Factor \\
$\begin{array}{l}\text { Interoper } \\
\text { ability }\end{array}$ \\
\end{tabular}} & \multicolumn{8}{|c|}{ Reference } \\
\hline & \multirow{2}{*}{$\begin{array}{l}\text { Sr. } \\
\text { No }\end{array}$} & \multirow{2}{*}{$\begin{array}{l}\text { Nature of } \\
\text { Subject }\end{array}$} & \multirow{2}{*}{ Age of Reference } & \multicolumn{3}{|c|}{ Publisher } & \multicolumn{2}{|c|}{ Citation } \\
\hline & & & & International & National & Verbal/Oral & International & National \\
\hline & \multirow[t]{5}{*}{1} & \multirow{5}{*}{$\begin{array}{l}\text { Qualitative/ } \\
\text { Gender in } \\
\text { Oral History } \\
\text { :A Critical } \\
\text { Analysis of } \\
\text { F.W. } \\
\text { Skemp's, } \\
\text { Multani } \\
\text { Stories }\end{array}$} & 1980 (Stimulate) & & $\begin{array}{ll}\checkmark & (\text { Yes } \\
\end{array}$ & & & $\checkmark$ (Yes) \\
\hline & & & 2007 (Response) & & $\checkmark$ (Yes) & & & $\checkmark$ (Yes) \\
\hline & & & 1997 (Response) & & (Yes) & & & $\checkmark$ (Yes) \\
\hline & & & 1909 (Stimulate) & $\checkmark \quad$ (Yes) & & & (Yes) & $\checkmark$ (Yes) \\
\hline & & & 1929 (Stimulate) & $\checkmark$ (Yes) & & & (Yes) & $\checkmark$ (Yes) \\
\hline & \multirow[t]{5}{*}{2} & \multirow{5}{*}{$\begin{array}{l}\text { Multani } \\
\text { Stories } \\
\text { collected } \\
\text { and } \\
\text { translated by } \\
\text { F.W. Skemp. } \\
1917\end{array}$} & $\begin{array}{l}1914 \\
\text { (Response) }\end{array}$ & & $\begin{array}{l}\text { (Sub-Continent) } \\
\text { To some extent }\end{array}$ & & $\begin{array}{ll}\checkmark & \text { (Yes) }\end{array}$ & \\
\hline & & & $\begin{array}{l}1787 \\
\text { (Stimulate) }\end{array}$ & & & $\begin{array}{ll}\text { (Sub- } \\
\text { Continent) } \\
\text { No } \\
\end{array}$ & $\begin{array}{l}\text { Nil } \\
\text { (No) }\end{array}$ & $\begin{array}{l}\text { Nil } \\
\text { (No) }\end{array}$ \\
\hline & & & $\begin{array}{l}1893 \\
\text { (Stimulate) }\end{array}$ & & & $\begin{array}{l}\text { (Sub- } \\
\text { Continent) } \\
\text { No }\end{array}$ & $\begin{array}{l}\text { Nil } \\
\text { (No) }\end{array}$ & $\begin{array}{c}\text { Nil } \\
\text { (No) }\end{array}$ \\
\hline & & & $\begin{array}{l}1805 \\
\text { (Stimulate) }\end{array}$ & & & $\begin{array}{l}\text { (Sub- } \\
\text { Contiment) } \\
\text { No }\end{array}$ & $\begin{array}{l}\text { Nil } \\
\text { (No) }\end{array}$ & $\begin{array}{l}\text { Nil } \\
\text { (No) }\end{array}$ \\
\hline & & & $\begin{array}{l}1901-02 \\
\text { (Response) }\end{array}$ & & $\begin{array}{l}\text { (Sub-Continent) } \\
\text { To some extent }\end{array}$ & & & $\checkmark$ (Yes) \\
\hline
\end{tabular}

\section{Table.17Relationship of correctness with interoperability}

In above table the factor of interoperability basically consist on the age of reference regarding its use in that time span when any particular subject was under seen. Here in the above table 17, the reference of 1980, 2007 , 1997 showing the detail which is use in national publication and its citation also available on national level while on the other hand in the other reference which is used in 1909 and 1929 are use in international publication and while their citation also available at the international level and national level. In the second reference which is related to the Multani stories collected and transla ted, in this the reference of 1914 and 1901-02 available in national level in subcontinent and the refere nce of 1987,1893, 1805 are available in the verbal/ oral level publication and the citation also not available in international or national level. Interoperability has two variations either it is stimulated or it is in a responsive manner. The concept of stimulation is in which the age of the reference is above than 20 years, whereas the term of response indicate such a reference which can interact with the facts of grounded theory and has a prominent aspect (response) in that era. Response will be within the age of 20 years and will show a positive effect on today, (Skemp, 1917)(Sohail, 2014 ).

\begin{tabular}{|c|c|c|c|c|c|c|c|c|}
\hline \multirow{13}{*}{$\begin{array}{l}\text { Onderstabe } \\
\text { aboiey }\end{array}$} & \multicolumn{8}{|c|}{ Meference } \\
\hline & \multirow{3}{*}{$\frac{\text { gr: }}{\text { No }}$} & \multirow{6}{*}{ 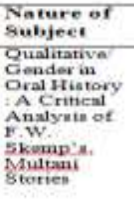 } & \multirow{4}{*}{ 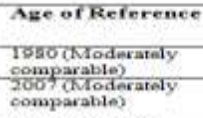 } & \multicolumn{3}{|c|}{ Publisher } & \multicolumn{2}{|c|}{ Citadon } \\
\hline & & & & Tmermaбonal & Nackonal & Vevbaloral & TwtermaвอพаI & Narional \\
\hline & & & & & $\checkmark \mathrm{Cran}$ & & & $\checkmark C \mathrm{Con}$ \\
\hline & & & & & 7 CXen & & & $P$ (xea) \\
\hline & & & $\begin{array}{l}\text { Togradot at al } \\
\text { eomparables }\end{array}$ & & (nes) & & & $\checkmark(V)=$ \\
\hline & & & $\begin{array}{l}1909 \text { dNet at all } \\
\text { compursobles }\end{array}$ & $\checkmark(Y)=$ & & & $(Y e 0)$ & $\checkmark(X \in)$ \\
\hline & & & $\begin{array}{l}1929 \text { (Not at all } \\
\text { comparsble) }\end{array}$ & $\checkmark$ CYN & & & (Ye) & $\nabla(X e)$ \\
\hline & 2 & $\begin{array}{l}\text { Multani } \\
\text { storios }\end{array}$ & $\begin{array}{l}191 \text { d cixwemaly } \\
\text { comparables }\end{array}$ & & $\begin{array}{l}\text { (sub-Contioment) } \\
\text { To nome notme }\end{array}$ & & CYan & \\
\hline & & $\begin{array}{l}\text { mad } \\
\text { translated by }\end{array}$ & $\begin{array}{l}\text { 1797 cNot at all } \\
\text { comparabie) }\end{array}$ & & & Conb. & $\begin{array}{l}\text { NaI } \\
\text { (No) }\end{array}$ & Noi \\
\hline & & & $\begin{array}{l}1899 \text { angt of al } \\
\text { complat able) }\end{array}$ & & & $\begin{array}{l}\text { sub- } \\
\text { Coblimeno } \\
\text { No }\end{array}$ & Nai & Nal \\
\hline & & & $\begin{array}{l}1805 \text { (Not at all } \\
\text { compuratble) }\end{array}$ & & & Conb- & No & (Ni \\
\hline & & & $\begin{array}{l}1901-02 \\
\text { CModerntely } \\
\text { comparsble) }\end{array}$ & & $\begin{array}{l}\text { (8ub-Continent) } \\
\text { To some extent }\end{array}$ & & & $(x \in)$ \\
\hline
\end{tabular}

Table.18Relationship of correctness with understandability

2288 | P a g e 
Understandability is a factor which helps the researcher to understand the importance of any reference in his work. Here in the above table 11, the reference of 1980,2007, 1997 showing the detail which is use in national publication and its citation a lso available on national level while on the other hand in the other reference which is used in 1909 and 1929 are use in international publication and while their citation also available at the international level and national level. In the second reference which is related to the Multani stories collected and translated, in this the reference of 1914 and $1901-02$ available in national level in subcontinent and the reference of 1987,1893, 1805 are available in the verbal/ oral level publication and the citation also not available in international or national level. Understandability acquires such modules which show a comparison statement regarding the age of a reference these comparisons are to be extreme, moderate and not comparable. This comparison of the understating regarding any reference is done which respect to the need of the time. This need of time is separated in a sequence regarding today. Understandability is such a factor which is dependent on its own and is based on the need of the researcher, (Skemp, 1917)(Sohail, 2014 ).

\begin{tabular}{|c|c|c|c|c|c|c|c|c|}
\hline \multirow{3}{*}{$\begin{array}{l}\text { Factor } \\
\begin{array}{l}\text { Modifi } \\
\text { ability }\end{array}\end{array}$} & \multicolumn{8}{|c|}{ Reference } \\
\hline & \multirow{2}{*}{ Sr.No } & \multirow{2}{*}{$\begin{array}{l}\text { Nature } \\
\text { of } \\
\text { Subject }\end{array}$} & \multirow{2}{*}{ Age of Reference } & \multicolumn{3}{|c|}{ Publisher } & \multicolumn{2}{|c|}{ Citation } \\
\hline & & & & International & National & Verbal/Oral & International & National \\
\hline & \multirow[t]{5}{*}{1} & \multirow{5}{*}{$\begin{array}{l}\text { Qualitati } \\
\text { ve' } \\
\text { Gender } \\
\text { in Oral } \\
\text { History: } \\
\text { A } \\
\text { Critical } \\
\text { Analysis } \\
\text { of F.W. } \\
\text { Skemp's, } \\
\text { Mylltani } \\
\text { Stories }\end{array}$} & 1980 (Moderate) & & $\checkmark \quad$ (Yes) & & & $\checkmark$ (Yes) \\
\hline & & & 2007(Moderate) & & $\checkmark \quad$ (Yes) & & & $\checkmark$ (Yes) \\
\hline & & & 1997 (Easily) & & $\checkmark$ (Yes) & & & $\checkmark$ (Yes) \\
\hline & & & 1909 (Easily) & $\checkmark$ (Yes) & & & $\begin{array}{ll} & \text { (Yes) }\end{array}$ & $\checkmark$ (Yes) \\
\hline & & & 1929 (Easily) & $\checkmark$ (Yes) & & & $\checkmark \quad$ (Yes) & $\checkmark$ (Yes) \\
\hline & \multirow[t]{5}{*}{2} & \multirow{5}{*}{$\begin{array}{l}\text { Myltani } \\
\text { Stories } \\
\text { collected } \\
\text { and } \\
\text { translated } \\
\text { by F.W. } \\
\text { Skemp. } \\
1917\end{array}$} & 1914 (Easily) & & $\begin{array}{ll}\text { (Sub-Continent) } \\
\text { To some extent }\end{array}$ & & $\checkmark \quad$ (Yes) & \\
\hline & & & 1787(Easily) & & & $\begin{array}{l}\checkmark \text { (Sub-Continent) } \\
\text { No }\end{array}$ & $\begin{array}{l}\mathrm{Nil} \\
\text { (No) }\end{array}$ & $\begin{array}{l}\mathrm{Nil} \\
\text { (No) }\end{array}$ \\
\hline & & & 1893 (Easily) & & & $\begin{array}{l}\text { (Sub-Continent) } \\
\text { No }\end{array}$ & $\begin{array}{l}\mathrm{Nil} \\
\text { (No) }\end{array}$ & $\begin{array}{l}\mathrm{Nil} \\
\text { (No) }\end{array}$ \\
\hline & & & 1805(Easily) & & & $\begin{array}{l}\text { (Sub-Continent) } \\
\text { No } \\
\end{array}$ & $\begin{array}{l}\mathrm{Nil} \\
\text { (No) }\end{array}$ & $\begin{array}{c}\text { Nil } \\
\text { (No) }\end{array}$ \\
\hline & & & 1901-02 (Easily) & & $\begin{array}{ll}\checkmark & \text { (Sub-Continent) } \\
\text { To some extent }\end{array}$ & & & (Yes) \\
\hline
\end{tabular}

\section{Table.19Relationship of correctness with modifiability}

Modifiability is that factor which is use in terms on the modification of any reference with today passage of time. This modification is done time to time by looking at the concepts of grounded theory in today's sphere. Today sphere describes what the needs of research in the existing environment are. Modifiability has the attributes of any reference to be easily modifiable will have a large age where as moderate and non moderate will be close to the existing time era. It to be seen that time and modules of modifiability have a inversely proportional relationship, (Skemp, 1917)(Sohail, 2014 ). Here in the above table 19, the reference of 1980, 2007,1997 showing the detail which is use in national publication and its citation also available on national level while on the other hand in the other reference which is used in 1909 and 1929 are use in international publication and while their citation also available at the international level and national level. In the second reference which is related to the Multani stories collected and translated, in this the reference of 1914 and 1901-02 available in national level in subcontinent and the reference of 1987,1893, 1805 are available in the verbal/ oral level publication and the citation also not available in international or national level. 


\section{Validation and Verification model:}
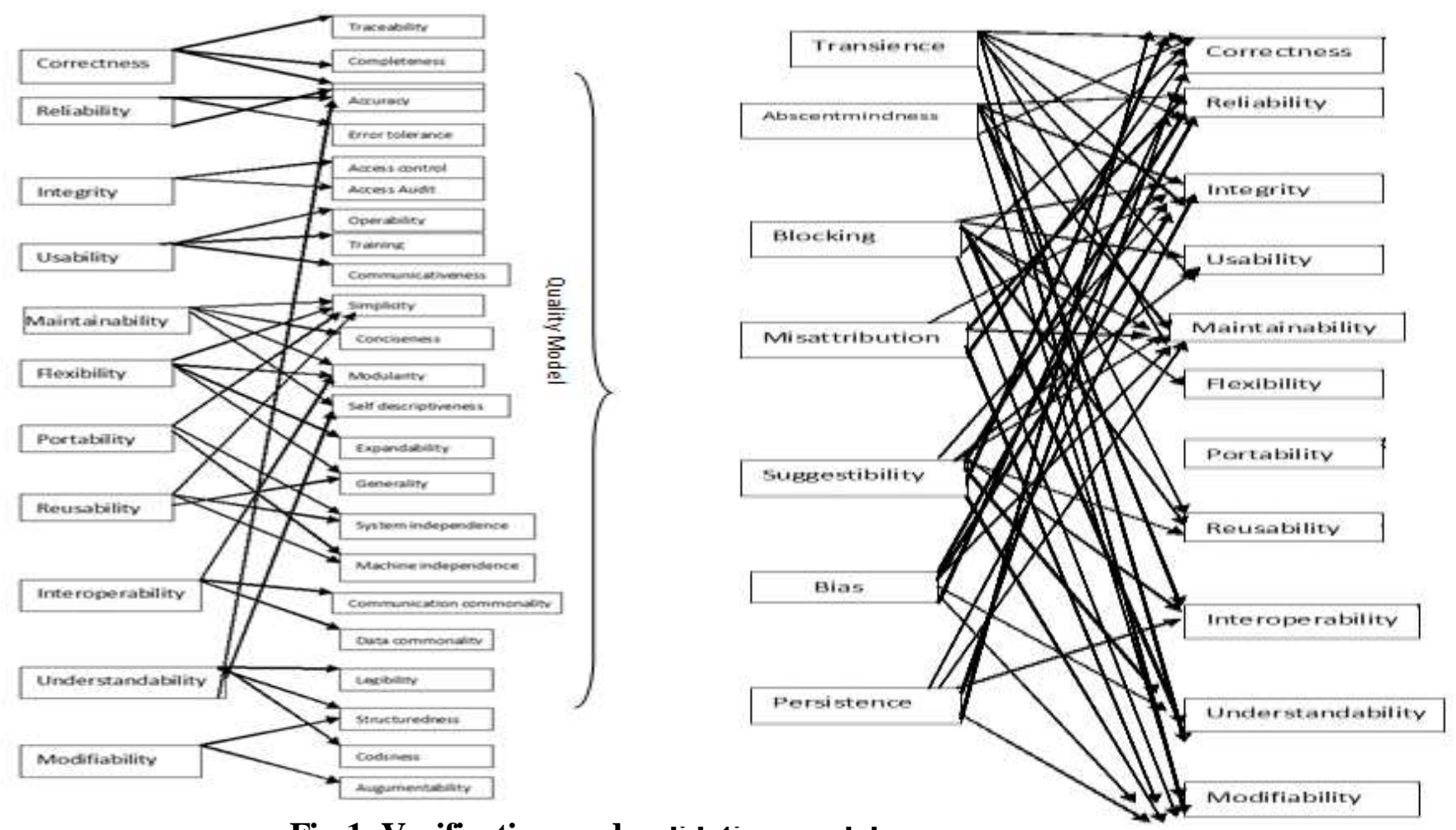

Fig 1. Verification and validation model

\section{Conclusion:}

In this study the workout regarding the verification and validation of the references which are used by the researchers of social sciences are seen in various situations with respect to the Age, Publisher and the Citation of the Reference. Giving a Model is an easywork to do but the main thing is to justify it. By applying test related to the Factor and the Reference a scale has been provided which varies from Factor to Factor and determines how to quote the reference. References in Social science related to a qualitative approach have a criterion of being from any age either old or new. To see the importance of judgment of giving the reference is determined by using a Quality Model. Such a model which verifies and validates the age of the reference to be quoted keeping in mind the signs of forgetting is given in a reachable and understandable manner for Social Scientists.

\section{References}

Kitchenham, B., Pfleeger, S. L. "Software Quality: the Elusive Target,"1996. IEEE Software, vol. 13, no. , pp.

Al-Qutaish, R. E., “Quality Models in Software Engineering Literature: An Analy tical and Comparative Study,"Journal of American Science, 2010. Vol. 6, no. 3, pp. 166-175.

Neuman.L. (1998). Social Research Method qualitative and quantitative approaches. University of Wisconsin at Whitewater.

Schacter, L. (n.d.). 'The Seven Sins of Memory Insights from Psychology and Cognitive Neuroscience. Harvard University, 54(3), 182203.

Skemp, W. (1917). Multani Stories collected and translated. In Multani Stories . Government of Punjab Printing Press.

Sohail, K. (2014 ). Gender in oral History: A Critical Analysis of F.W Skemp’s Multani Stories. Department of Gender Studies. 